\title{
UPAYA PENGELOLA PKBM UNTUK MENINGKATKAN KEMANDIRIAN WARGA BELAJAR KESETARAAN PAKET C MELALUI KEWIRAUSAHAAN
}

\author{
Cecep Wahyudin', Nunu Mahmud Firdaus ${ }^{2}$ \\ 1,2 IKIP Siliwangi \\ 1cecepwahyudin789@gmail.com,2mahmudfirdaus@gmail.com
}

\begin{abstract}
ABSTRAK
PKBM adalah suatu lembaga yang fokus terhadap pembinaan pendidikan dibidang non formal. Peneliti menganalisis manajemen pengelolaan PKBM pada aspek mutu dari peserta didik yang dibina pada PKBM tersebut. Penelitian ini merumuskan pada masalah pola manajemen dan implementasi pada peserta didik serta output peserta didik yang dibina. Metode yang digunakan peneliti adalah metode deskriptif dengan dengan menggunakan pedoman observasi sebagai alat ukurnya dan menggunakan objek penelitian PKBM dan peserta didiknya. Hasil penelitian ini diperoleh bahwa perencanaan kegiatan pelatihan vokasional untuk warga belajar PKBM, seluruhnya (100\%) menjawab sangat baik ada perencanaan terlebih dahulu sebelum program kegiatan dilaksanakan, sednagkan yang menjawab tidak usah ada perencanaan, biasa-biasa saja serta tidak dapat dimengerti tidak ada yang menjawab (0\%).
\end{abstract}

Kata Kunci: Pengelolaan, Kemandirian, Kewirausahaan

\section{PENDAHULUAN}

Salah satu tujuan pembangunan nasional negara kita adalah pembangunan dibidang pendidikan nasional. Pendidikan nasional sebagai salah satu sistem dari supra sistem pembangunan nasional, memiliki dua subsitem pendidikan yaitu pendidikan sekolah dan pendidikan luar sekolah. Kedua subsistem ini memiliki andil dalam mencerdaskan bangsa. Sebagaimana tercantum dalam pembukaan Undang-undang Dasar 1945 yaitu "turut mencerdaskan kehidupan bangsa". Betapa tidak, pendidikan merupakan kunci keberhasilan pembangunan suatu negara dengan pendidikan manusia dapat mengembangkan potensi yang ada dalam dirinya melalui proses pembelajaran. Sebagaimana dinyatakan dalam (Undang-Undang Dasar, 1945) tentang Sistem Pendidikan Nasional BAB II Pasal 3 bahwa: "Pendidikan nasional berfungsi mengembangkan kemampuan dan membentuk watak serta peradaban bangsa yang bermartabat dalam rangka mencerdasakan kehidupan bangsa, bertujuan untuk mengembangkan potensi peserta didik agar menjadi manusia yang beriman dan bertaqwa kepada Tuhan yang Maha esa, berakhlak mulia, sehat, berilmu, cakap, kreatif, mandiri dan menjadi warga negara yang demokratis serta bertanggung jawab".

Salah satu jalur yang dapat mengantarkan kita kepada kualitas pendidikan yang mumpuni ialah melalui pendidikan nonformal (pendidikan luar sekolah). Hal ini dikarenakan pada jalur pendidikan ini terdapat kurikulum pembelajaran yang menekankan pada pengembangan diri dan liefskill seseorang. Senada dengan hal itu (Sudjana, 2004) Pendidikan mencakup semua komunikasi yang teroganisasi dan berkelanjutan yang diselenggarakan dalam kehidupan nyata di masyarakat, lingkungan keluarga, lembaga-lembaga, dunia kerja dan lingkungan kehidupan lainnya. Dalam 
kaitannya dengan pembangunan di negara-negara berkembang, meliputi pengembangan semua aspek kehidupan dengan menggarap program-program pendidikan yang berorientasi pada pengembangan sumber daya manusia untuk memenuhi kebutuhan tenaga kerja, lapangan usaha, kewirausahaan dan pembangunan pada umumnya.

Pendidikan nonformal yang dimaksud adalah pendidikan yang bisa menumbuhkan dan mengembangkan kepribadian yang lebih baik. Salah satu langkah dalam menumbuhkan dan mengembangkan karakter yang lebih baik ialah melalui lembaga pelatihan. Maraknya pelatihan-pelatihan motivasi dan pengembangan diri sangat membantu pemerintah dalam menanggulangi masalah kehidupan sosial yang ada. Salah satu pelatihan motivasi dan pengembangan diri yaitu pelatihan kewirausahaan. Pelatihan sebagai salah satu satuan pendidikan nonformal sebagaimana tercantum dalam (Undang-Undang Dasar, 1945) Sistem pendidikan Nasional, bahwa "Satuan pendidikan nonformal terdiri atas lembaga kursus, lembaga pelatihan, keompok belajar, pusat kegiatan masyarakat, dan majelis taklim, serat satuan pendidikan yang sejenis".

Salah satu lembaga penyelenggara pelatihan motivasi, pengembangan diri dan kewirausahaan adalah PKBM Bina Mandiri di Cimahi. Lembaga ini berperan sebagai sarana pemupuk semangat bagi warga belajar yang memiliki keinginan dan kemauan dalm meningkatkan pengembangan dirinya melalui kewirausahaan. Hal ini diperlukan agar dapat meningkatkan pengetahuan dan keterampilan diri bagi warga belajar tersebut dalam menghadapi tantangan dunia global sebagaimana tercantum dalam Undang - Undang Republik Indonesia Nomor 20 tahun 2003 tentang sistem Pendidikan Nasional BAB VI bagan kelima pasal 26 ayat 2 bahwa, Pendidkan nonformal berfungsi mengembangkan potensi peserta didik dengan penekanan pada penguasaan pengetahuan dan keterampilan fungsional serta pengembangan sikap kepribadian profesional". Dan ayat 5, bahwa : Kursus san pelatihan diselenggarakan bagi masyarakat yang memerlukan bekal pengetahuan, keterampilan, kecakapan hidup dan sikap untuk mengembangkan diri, mengembangkan profesi, bekerja, usaha mandiri dan atau melanjutkan pendidikan ke jenjang yang lebih tinggi.

Sistem pembelajaran yang telah disebutkan di atas dapat menjadi faktor penentu motivasi belajar peserta pelatihan kewirausahaan, baik rendah pada sebagian warga belajar, namun masih ada warga belajar yang memiliki motivasi belajar yang cukup tinggi dengan dibuktikan pada proses pembelajaran di kesehariannya. Seperti rajin mengikuti seluruh ranngkaian proses belajar pada pelatihan tersebut, aktif ketika proses kegiatan belajar berjalan, dan sapat mempraktikan secara baik bagaimana menjadi seorang wirausaha. Sejalan dengan pernyataan Firmansyah (2018) lingkungan mempengaruhi cara berpikir dan berkembangnya keterampilan penunjang karir pada manusia.

Berkaitan dengan proses belajar di atas, maka akan ada hasil belajar dari pelatihan kewirausahaan yang didapatkan. Salah satu hasil belajar yang didapatkan ialah kemampuan mandiri dalam mengembangkan usaha produksi kerajinan tangan. Usaha yang dilakukan oleh 11 Warga belajar ini telah dijalnkan selama dua tahun. Selama itu pula, seluruh warga belajar tersebut. Jika dilihat dari degi keuntungan, omset yang dapat didapat setiap bulannya sekitar Rp. 500.000 sampai Rp. 1.000.000,00. Suatu 
angka yang cukup baik bagi warga belajar usia remaja seperti mereka dengan latar belakang ekonomi yang kurang.

Bertalian dengan hal-hal yang telah dipaparkan, peneliti telah mengamati proses pembelajarana yang diberikan instruktur dan hasil yang diraih dari ke 22 Warga belajar dengan berbagai perbedaan pencapaian hasil belajar tersebut. Ada sebagian warga yang begitu antusias dalam mengikuti pelatihan kewirausahaan sehingga mampu membangun suatu usaha bersama di bidang produksi keterampilan tangan dengan berbagai kemampuan dan kemandirian yang dimiliki. Namun, ada pula warga belajar yang kurang antusias dalam mengikuti pelatihan tersebut, sehingga dapat dilihat hasil belajar yang kurang memuaskan dari segi sikap belajar dan kemampuan lainnya. Tentunya semua ini berkaitan dengan motivasi yang ada pada diri warga belajar tersebut.

Pelatihan kewirausahaan ini merupakan salah satu langkah instruktur dalam memperkuat dan meningkatkan motivasi belajar warga yang telah ada. Penguatan motivasi belajar berada di tangan instruktur sebagai tenaga pendidik, dan tentunya keluarga serta anggota masyarakat lainnya. Jika langkah-langkah dalam memperkuat dan meningkatkan motivasi belajar peserta didik dilakukan dengan baik, maka motivasi belajar yang ada akan sangat berperan aktif dalam meningkatkan kualitas diri peserta dalam hal ini belajarnya. Oleh karena itu melihat dua kondisi yang ada, maka peneliti ingin meneliti mengenai seberapa besar peranan instruktur dalam menumbuhkan motivasi belajar seorang dan hasil belajar yang diharapkan dengan menggunakan strategi pembelajaran yang ada dalam pelatihan kewirausahaan sebagai salah satu stimulan dari instruktur kepada warga belajarnya.

Kemandirian merupakan suatu hal yang penting dan hairus dimiliki setiap manusia agar tidak selalu bergantung kepada orang lain. Seseorang dikatakan mandiri apaabila dirinya telah mampu menyelesaikan permasalahannya sendiri tanpa bergantung kepada orang lain. Orang yang mandiri mampu mengatur hidupnya sendiri dalam kesehariannya. Fatimah menjelaskan bahwa manusia terlahir dalam kondisi yang tidak berdaya yang membuat manusia itu akan bergantung pada orang tua dan orang-orang yang berada di lingkungannya hingga waktu tertentu. Seiring dengan berjalannya waktu dan berkembangnya anak, seorang anak perlahan-lahan akan melepaskan diri dari ketergantungannya dengan orang tua atau orang lain disekitarnya dan mulai bel[ajar untuk mandiri. Hal ini merupakan suatu proses alamiah yang dialami oleh manusia. Mandiri atau sering juga disebut berdiri diatas kaki sendiri merupakan kemampuan sesorang untuk tidak bergantung kep[ada orang lain, terutama orang tua dan orangorang disekitarnya serta dapat bertanggung jawab atas semua hal yang telah dilakukannya (2010:141).

Dalam Desmita istilah "kemandirian" berasal dari kata dasar "diri" dengan awalan "ke" dan akhiran "an. Karena kemandirian berasal dari kata dasar "diri", maka kemandirian selalu dikaitkan dengan kata siri itu sendiri, yang dalam konsep Carl Rogers disebut dengan istilah self, karena diri itu merupakan inti dari kemandirian. Kewirausahaan adalah padanan kata dari entrepreneurship dalam bahasa Inggris, unternehmer dalam bahasa Jerman, ondernemen dalam bahasa Belanda. Sedangkan di Indonesia diberi nama kewirausahaan. Kata entrepreneurship sendiri sebenarnya berawal dari bahasa Prancis yaitu "entreprende" yang berarti petualang, pencipta, dan pengelola usaha. Istilah ini 
diperkenalkan pertama kali oleh (Catillon, 1755). Istilah ini makin populer setelah digunakan oleh pakar ekonomi untuk menggambarkan para pengusaha yang mampu memindahkan sumber daya ekonomis dari tingkat produktivitas rendah ke tingkat yang lebih tinggi serta menghasilkan lebih banyak lagi.

Kewirausahaan merupakan kemampuan dalam menciptakan sesuatu yang baru dan berbeda. Definisi tersebut secara lebih luas dikemukakan oleh Hisrich dalam Suryana, yang mengatakan bahwa kewirausahaan adalah proses penciptaan sesuatu yang berbeda untuk menghasilkan nilai dengan mencurahkan waktu dan usaha, diikuti penggunaan uang, fisik, risiko, dan kemudian menghasilkan balas jasa berupa uang serta kepuasan dan kebebasan pribadi. Sementara itu, (Norman Scarborough, Doug Wilson, 2008) mengartikan kewirausahaan sebagai suatu proses penerapan kreativitas dan inovasi dalam memecahkan persoalan dan menemukan peluang untuk memperbaiki kehidupan (usaha).

\section{METODE}

Pendekatan penelitian ini adalah "kualitatif", atau disebut juga penelitian kualitatif yaitu menyelidiki kualitas suatu objek kegiatan yang digunakan untuk mengungkapkan kenyataan yang ada dilapangan. Penelitian kualitatif dapat menyelami masalah sedalam-dalamnya secara holistik dan integral, yang dapat dilakukan dengan cara wawancara, observasi dan studi dokumentasi, yang bahwa peneliti dapat ikut berpartisipasi langsung dalam kegiatan yang akan diteliti, peneliti dapat mengamati orang dalam lingkungan hidupnya, berinteraksi dengan mereka, memahami bahasa dan tafsiran mereka tentang dunia sekitarnya. Moleong, (2004) mendefinisikan pendekatan kualitatif sebagai "prosedur penelitian yang menghasikan data deskriptif berupa katakata atau lisan dari orang-orang dan perilaku yang dapat diamati".

\section{HASIL DAN PEMBAHASAN}

Berdasarkan data penelitian diperoleh bahwa perencanaan kegiatan pelatihan vokasional untuk warga belajar PKBM, seluruhnya (100\%) menjawab sangat baik ada perencanaan terlebih dahulu sebelum program kegiatan dilaksanakan, sednagkan yang menjawab tidak usah ada perencanaan, biasa-biasa saja serta tidak dapat dimengerti tidak ada yang menjawab (0\%), jadi kesimpulan jawaban responden sudah terlihat jelas, sebelum kegiatan program pelatihan vokasional harus ada perencanaan terlebih dahulu. Pelaksanaan Penelitian terhadap peserta didik dengan cara menyebarkan angket sebanyak 6 orang sesuai dengan jumlah sampel yang teliti, yaitu 1 orang pengelola, 1 orang tutor dan 4 orang peserta didik.

Salah satu tolak keberhasilan pembinaan kemandirian warga belajar kesetaraan melalui kewirausahaan pada PKBM Bina Mandiri, dapat dilihat dari dorongan warga belajar untuk mengikuti kegiatan kewirausahaan pada PKBM, sebagaimana tersaji dalam tabel berikut ini : 


\section{Tabel 1}

Pernyataan Responden Tentang Dorongan Mengikuti Kegiatan Pembinaan Kewirausahaan Pada Pkbm

\begin{tabular}{clcc}
\hline No & \multicolumn{1}{c}{ Alternatif Jawaban } & F & $\%$ \\
\hline 1 & Kebutuhan & 4 & 80 \\
2 & Ikut / diajak teman & 1 & 10 \\
3 & Diharuskan keluarga & 0 & 0 \\
4 & Iseng saja & 1 & 10 \\
\hline & & 6 & 100
\end{tabular}

Sumber : Angket Bagian II. B Nomor 2

Tabel di atas menggambarkan bahwa sebagian besar (80\%) responden menyatakan kebutuhan sebanyak 4 orang, 1 orang menjwab ikut/diajak teman, dan yang menjawab iseng saja sebanyak 1 orang, sedangkan yang menjawab diharuskan keluarga tidak ada $(0 \%)$.

Tabel 2

Pernyataan Responden Tentang Usaha Untuk Lebih Memahami Kegiatan Kewirausahaan

\begin{tabular}{cllc}
\hline No & \multicolumn{1}{c}{ Alternatif Jawaban } & F & $\%$ \\
\hline 1 & Membaca buku kewirausahaan & 3 & 70 \\
2 & Bertanya pada tutor PKBM & 1 & 10 \\
3 & $\begin{array}{l}\text { Mengikuti diklat kewirausahaan } \\
\text { pada PKBM } \\
\text { Mengikuti setiap ada kegiatan } \\
\text { kewirausahaan pada PKBM }\end{array}$ & 1 & 10 \\
$\quad$ Jumlah & 6 & 10 \\
\hline & \multicolumn{1}{c}{100} \\
\hline
\end{tabular}

Tabel di atas menggambarkan bahwa sebagian besar (70\%) responden menyatakan membaca buku kewirausahaan sebanyak 1 orang (10\%), yang menjawab bertanya pada tutor PKBM sebanyak 1 orang (10\%), responden yang menjawab mengikuti diklat kewirausahaan pada PKBM 1 orang (10\%), dan responden yang menjawab mengikuti setiap ada kegiatan kewirausahaan pada PKBM berjumlah 1 orang (10\%).

Selanjutnya mengenai sumber informasi tentang kegiatan kewirausahaan pada PKBM, dapat dilihat pada tabel berikut ini.

Tabel 3

Pernyataan Responden Tentang Sumber Informasi

\begin{tabular}{cccc}
\hline No & Alternatif Jawaban & f & $\%$ \\
\hline 1 & Langsung dari tutor PKBM & 3 & 70 \\
\hline
\end{tabular}




\begin{tabular}{cccc}
\hline No & Alternatif Jawaban & f & $\%$ \\
\hline 2 & Brosur/edaran & 1 & 10 \\
3 & Teman - teman & 1 & 10 \\
4 & Datang sendiri ke PKBM & 1 & 10 \\
\hline & Jumlah & 6 & 100 \\
\hline
\end{tabular}

Tabel di atas memberi gambaran bahwa hampir seluruhnya (70\%) responden menyatakan langsung dari tutor PKBM sebanyak 3, yang menjawab melalui brosur/edaran sebanyak 1 orang (10\%), responden yang menjawab mengetahui dari teman-teman sebanyak 1 orang, dan 1 orang $(10 \%)$ responden menjawab datang sendiri ke PKBM.

Tabel 4.10

Pernyataan Responden Tentang Frekuensi Kegiatan Pembinaan Kewirausahaan Pada Pkbm

\begin{tabular}{cccc}
\hline No & Alternatif Jawaban & F & $\%$ \\
\hline 1 & Satu kali & 4 & 80 \\
2 & Dua kali & 1 & 10 \\
3 & Tiga kali & 1 & 10 \\
4 & Lebih dari tiga kali & 0 & 0 \\
\hline & Jumlah & 6 & 100 \\
\hline
\end{tabular}

Tabel di atas memberi gambaran bahwa responden yang menjawab satu kali kegiatan sebanyak 4 orang (80\%), yang menjawab dua kali kegiatan sebanyak 1 orang $(10 \%)$ dan yang menjawan tiga kali kegiatan sebanyak 1 orang, sedangkan yang menjawab lebih dari tiga kali tidak ada (0\%).

Tabel 4.11

Pernyataan Responden Tentang Tempat Diadakannya Pembinaan

Kewirausahaan Pada Pkbm

\begin{tabular}{cccc}
\hline No & Alternatif Jawaban & F & $\%$ \\
\hline 1 & Ditempat usaha & 0 & 0 \\
2 & Dirumah warga belajar & 0 & 0 \\
3 & Di gedung PKBM & 6 & 0 \\
4 & Dilapangan terbuka & 0 & 0 \\
\hline & Jumlah & 6 & 100
\end{tabular}

Tabel diatas menggambarkan bahwa seluruhnya (100\%) dari responden menjawab diadakannya kegiatan pembinaan di gedung PKBM. 
Tabel 4.12

Pernyataan Responden Tentang Pemberian Bantuan Untuk Meningkatkan Keberhasilan Kegiatan

\begin{tabular}{clcc}
\hline No & \multicolumn{1}{c}{ Alternatif Jawaban } & F & $\%$ \\
\hline 1 & Selalu berusaha membantu & 3 & 70 \\
2 & Mencari donator & 2 & 20 \\
3 & $\begin{array}{l}\text { Membujuk banyak orang untuk mengikuti } \\
\text { kegiatan }\end{array}$ & 1 & 10 \\
\hline & Tidak pernah berusaha membantu & 0 & 0 \\
\hline Jumlah & 6 & 100 \\
\hline
\end{tabular}

Tabel diatas memberi gambaran bahwa 3 orang responden (70\%) menyatakan selalu berusaha mencari bantuan untuk kegiatan PKBM, responden yang menjawab mencari donator sebanyak 2 orang (20\%), dan responden yang menjawan membujuk banyak orang untuk mengikuti kegiatan sebanyak 1 orang (10\%), sedangkan responden yang menjawab tidak pernah berusaha membantu tidak ada $(0 \%)$.

\section{Hasil Pelatihan Kewirausahaan Yang Dapat Meningkatkan Kemandirian Warga Belajar}

Hasil belajar merupakan hal yang berhubungan dengan kegiatan belajar karena kegiatan belajar merupakan proses sedangkan hasil belajar adalah sebagian hasil yang dicapai seseorang setelah mengalami proses belajar dengan terlebih dahulu mengandakan evaluasi dari proses belajar yang dilakukan. Hasil belajar merupakan hasil dari suatu interaksi tindak belajar dan tindak mengajar. Dari sisi guru, tindak mengajar diakhiri dengan proses evaluasi hasil belajar. Dari sisi siswa, hasil belajar merupakan berakhirnya pengajaran dari puncak proses belajar.

Dalam penelitian ini, peneliti menggunakan dua kriteria untuk mengetahui hasil belajar Pelatihan Keterampilan dalam Meningkatkan Kemandirian Warga Belajar Kesetaraan Melalui Kewirasusahaan di PKBM Bina Mandiri Cipageran dalam kaitannya dengan upaya meningkatkan kemandirian peserta didik yaitu kemampuan peserta didik dalam mengembangkan keterampilan yang telah di dapat dalam program pelatihan kewirausahaan dengan baik.

Salah satu faktor keberhasilan dalam kewirausahaan dapat diukur atau diketahui dari ketekukan peserta didik mengikuti pelatihan dan tugas ahir praktek. Kemandirian peserta didik ditentukan oleh kemampuan peserta didik menghasilkan tugas ahir yang bisa di jual pada masyarakat. Mengingat kondisi dan hambatan perlu mengembangkan kemampuan dalam pemasaran, maka itu PKBM membantu pemasaran hasil pelatihan kewirausahaan peserta didik.

\section{SIMPULAN}

Berdasarkan hasil penelitian yang sudah diperoleh yaitu Upaya Pengelola PKBM Untuk Meningkatkan Kemandirian Warga Belajar Kesetaraan Melalui Kewirasuahaan di PKBM Bina Mandiri Cipageran, maka dapat ditarik kesimpulan bahwa: 
Perencanaan Upaya Pengelola PKBM Untuk Meningkatkan Kemandirian Warga Belajar Kesetaraan Melalui Kewirasuahaan di PKBM Bina Mandiri Cipageran dilakukan dengan cara perumusan tujuan pembelajaran, pemilihan jenis pelatihan vokasional, membuat perencanaan yang matang, perencanaan tindakan, dan persiapan bahan mengajar. Dalam merencanakan pembelajaran, pengelola dan guru memiliki tanggung jawab dan berdedikasi yang tinggi. Guru mampu merencanakan pembelajaran yang interaktif dan dapat digunakan untuk mengeksplorasi semua potensi yang dimiliki oleh setiap peserta didik.

Pelaksanaan Upaya Pengelola PKBM Untuk Meningkatkan Kemandirian Warga Belajar Kesetaraan Melalui Kewirasuahaan di PKBM Bina Mandiri Cipageran pembelajaran sesuai dengan rencana pelaksanaan pembelajaran yang telah disusun sebelumnya, guru melaksanakan pembelajaran Pelatihan Kewirasuahaan dalam Meningkatkan Kemandirian Warga Belajar di PKBM Bina Mandiri Cipageran dalam tiga tahap kegiatan, yakni tahap kegiatan awal, kegiatan inti, dan kegiatan akhir. Pada pelaksanaan pembelajaran, guru cukup menguasai teknik pembelajaran Pelatihan Keterampilan dalam Meningkatkan Kemandirian Warga Belajar di PKBM Bina Mandiri Cipageran sehingga memotivasi peserta didik untuk berinteraksi secara aktif dan kreatif, peserta didik juga menunjukkan kepedulian, tekun dalam praktek pelatihan vokasi. Guru berhasil menciptakan suasana belajar di kelas yang kondusif.

Kegiatan Pelatihan Kewirausahaan dalam Meningkatkan Kemandirian Warga Belajar di PKBM Bina Mandiri Cipageran terbukti mampu meningkatkan kemandirian peserta didik di PKBM Bina Mandiri Cipageran. Peserta didik mampu memasarkan sendiri hasil pelatihan kewirausahaan. Pembelajaran kewirasuahaan merupakan alternatif strategis yang dipandang dapat menumbuhkembangkan kemandirian peserta didik yang ada di PKBM Bina Mandiri Cipageran. 


\section{DAFTAR PUSTAKA}

Catillon, R. (1755). Entrepreneurial is an Innovator and Individual Developing Something Unique and New. New York: Liberty.

Firmansyah, D. (2018). Analysis of Language Skills in Primary School Children (Study Development of Child Psychology of Language). PrimaryEdu - Journal of Primary Education, 2(1), 35-44. https://doi.org/10.22460/pej.v1i1.668

Indonesia, R. Undang-undang Dasar Negara Republik Indonesia Tahun 1945 (1945). Indonesia.

Moleong, L. J. (2004). Metodologi Penelitian Kualitatif. Bandung: Remaja Rosdakarya.

Mulyono, D. (2018). The Strategy Of Managers In Moving Business Learning Group Program In PKBM Srikandi Cimahi City. Journal of Educational Experts (JEE), 1(1), 37-44.

Norman Scarborough, Doug Wilson, T. Z. (2008). Kewirausahaan dan Manajemen Usaha Kecil. Jakarta: Salemba Empat.

Sudjana. (2004). Dasar-Dasar Proses Belajar Mengajar. Bandung: Sinar Baru Algensido. 